\title{
Legacies of Colonialism in Africa
}

\author{
Dr. Prisca A. Gobo \\ Faculty of Humanities \\ Department of History and Diplomatic Studies \\ University of Port Harcourt
}

\begin{abstract}
There appears to be a general paucity of literature on the legacies of colonialism and the impact on Africa. This informed the decision to examine this colonial legacy which is so deep rooted and enduring. This paper attempts to provide clarity to the narrative of the present state of affairs in Africa in its broadest sense. This research seeks to interpret their experience and guide their actions towards reconciling their dilemmas. The continuity between past and present is often neglected or trivialized with its attendant negative consequences for the development of the African continent.
\end{abstract}

Given these legacies, what are the consequences of this past, how have they changed how we live, who we are and our hope for the future. This paper interrogates the various forces working against development in Africa, their origins and effects and to proffer some solutions. This research is by no means exhaustive but it will provide a starting point for more research. Approaching these issues from a multi-disciplinary context, the paper concludes by exploring new strategies and making useful recommendations towards ensuring a more stable and progressive Africa.

Keywords:- Legacies, Colonialism, Africa.

\section{INTRODUCTION}

Africa is a vast continent rich in human and natural resources. It is a misnomer that the most blessed continent of the world (Africa) in terms of natural and human resources is also the poorest continent in the world giving various world organizations the right or reason to fight "African poverty", the same poverty they helped to create.

It is important to know these colonial histories and emphasize the important role of colonialism in understanding the past and its influence on the present. Understanding the dynamics of the colonial legacy is a sure way of reviewing, rethinking and changing existing strategies for African development.

My point is that colonialism left a deep and enduring legacy on the African continent which is partly responsible for the state of affairs in Africa. This paper is a contribution to the development/underdevelopment debate because understanding the colonial history and correcting the negative outcomes of this legacy is a definite positive step towards development.

\section{HISTORY OF COLONIAL LEGACY}

The relationship between Africa and Europe began with European imperialism in the fifteenth century. According to Robinson and Gallagher, Imperialism is "a sufficient political function of the process of integrating new regions into an expanding economy". (]Robinson and Gallagher, 1953:5). By the end of the eighteenth century, European economy had expanded so much due to the Industrial Revolution that it became necessary to integrate Africa as a market to dump their excess products and a source of raw materials to feed the European Industries. Imperialism was therefore the first in the continuum of the relationship between Africa and Europe. This stage continued until it became necessary to change the relationship to outright colonization which became the second in the continuum.

Colonialism did not last as long as imperialism because by the mid-twentieth century, it had become imperative to end colonialism due to developments at the time. These developments were World War II and the effect on Africans who fought in the war, the increasing number of the educated elites, the growth in political consciousness and the trade union movement. These compelled the colonial governments to begin to consider decolonization which is the third in the continuum. Decolonization was immediately followed by neo-colonialism which is the fourth and last in the continuum. (Nwabughuogu, 2004:37).

Neo-colonialism is the most dangerous stage of this relationship because it operates in a subtle way. Kwame Nkrumah called it the "worst form of imperialism" and opined that "for those who practice it, it means power without responsibility and for those who suffer it, it means exploitation without redress". (Nwabughuogu, 2004:38). Neo-colonialism manipulates African countries through international control of the world markets; high interest on loans given to African countries by the World Bank and International Monetary Fund (IMF), capital aid to developing countries with humiliating conditions, domination through multinational corporations, the use of labour movement to destabilize the economy of African States, Evangelism and the use of the world media to manipulate events in Africa. Through these means, the developed nations continue to manipulate the African countries to ensure that the present uneven level of development in the world is preserved" (Hodgart, 1977:5455). And all these manipulations and activities of the developed nations in Africa create a situation of inevitability of instability affecting every facet of the African continent. 
It is pertinent to pay attention to the legacies of colonialism to get clarity on the challenges of the African states. The negative legacies of colonialism are so overwhelming and obvious that they neutralize the positive contributions of the colonial experience (if any). The legacy that was bequeathed to the post-colonial state by the colonial state and the impact of that legacy on African nations is so deep rooted that it has been difficult to create a new order without a radical departure from the prevailing order. (Makaye in Mangut and Wuam (eds.) 2012:845).

To recognize the foundation of many African problems, the history of colonialism cannot be ignored. Colonialism had only one hand - it was a one-armed bandit. Whether they ruled through direct or indirect rule, the goal was the same - exploitation, domination, and subjugation.

This is a worthy exercise, just like Chinue Achebe said, so that we can understand where the rain began to beat us and begin to retrace our steps. These legacies also came to inform the attitude and actions of those who succeeded in gaining political power in African countries. Although Africa has had centuries of contact with other nations of the world before the fifteenth century, the part of the crisis which now engulfs the continent had set in by the fifteenth century. For our purpose, the Trans-Atlantic Slave Trade which grew from the sixteenth through the nineteenth centuries ultimately laid a foundation for the external origins of the present African predicament. This is because it altered the nature of relationship between Europeans along the coast and the African. Since the major article of trade became the African, the respect and dignity which Africans hitherto commanded began to wane (Ogbogbo in Egbe (ed), 2002:274)

Due to the nature of the trade in slaves, there was an increase in the importation of weapons of warfare into Africa from Europe as an article of exchange and to arm the slave traders. This made the domination of Africa easier and turned the African into a mere article of trade that could be easily exchanged for a worthless item like mirror or gin. This is the origin of how the African lost his dignity and value as a human being.

Furthermore, the trade truncated the process of development in Africa and placed Africa in a relationship of dependency which has persisted until the present. And in addition, Africans became psychologically brutalized to the point of destroying their self-confidence and self-esteem. (Ogbogbo in Egbe (ed) 2002:278).

However, the legitimate trade in palm oil further worsened the situation and deepened the crisis. Enshrined in the mission of colonialism is the superiority complex which believed that the African has to be Christianized and civilized. These euphemisms had cultural implications. The European colonizer knew the supreme importance of culture and fearing the threat posed by men with confidence in their own history and cultural heritage, made the conquest a political, cultural and mental one.
The British on arrival in Nigeria treated our indigenous games and sports as savage, evil and un-Christian compared with Western sports like cricket, soccer and basketball. The result was to undermine the faith of young people in their culture and in themselves. (Alagoa and Derefaka (eds.), 2002:201). This is detrimental to the survival of the arts and culture of the colonized people.

\section{EFFECTS OF COLONIAL POLICIES ON AFRICA}

The various policies of the colonial powers impacted negatively on African people in many ways. The colonial school for example served as an instrument of oppression of the African children. First and foremost, it alienated the African child from his language root, his culture and traditions. The school children were punished for speaking their mother tongue in school and that is why even scholars today see their indigenous languages and culture as primitive. They further colonized the minds of the African children by providing them with books written in the language of the colonizer with content which presented them with an environment that was completely foreign to them. According to Onyemelukwe (2004:40) citing Ngugi (1981:18), the African child's "Native languages were associated in his impressionable mind with low status, humiliation, corporal punishment, slow-footed intelligence and ability or downright stupidity, non-intelligibility and barbarism."

The three most powerful colonizers were Britain, France and Spain and they have largely determined the languages of the world. As a result of colonialism, English is spoken in Canada, Australia, New Zealand, Belize, Nigeria, Ghana, South Africa, India, Pakistan, Bangladesh, Zimbabwe, Hong kong, Singapore, and the United States of America. French is spoken in Canada, Senegal, Tahiti, Haiti, Benin Republic, Cote d'ivoire, Niger, Rwanda, Mali, Chad, and the Central African Republic. Spanish is spoken in most of the Western Hemisphere, from Mexico to Chile, and Argentina, Cuba, Venezuela, Colombia and Panama. (Martin and Nakayama, 2005: 68).

Many foreign language textbooks proudly display maps of languages spoken in different parts of the world without revealing why those languages are widely spoken in those places; neither do they reveal the legacies of colonialism in those regions. Understanding the history of these places would help you understand the culture and language of the people. This negative colonial legacy has relegated African languages to the background and some of them are presently at the risk of extinction and this has a bearing on African cultural roots and identity.

This is a clear way of instilling in the colonized an inferiority complex which is still plaguing Africans till date. Thus, western education which is a major product of missionary activity and colonial governments reinforced the divisive tendencies in Africa between the educated and the illiterates which still affect Africa. 
Another weapon of colonialism was religion. The missionaries inculcated into Africans the erroneous belief that every aspect of African culture was fetish and devilish and deserved to be abandoned. This was a deliberate attempt to undervalue and destroy African culture and tradition including the visual and performing arts. These include: art, dance, drama, religion, history, education and geography, and by condemning the African culture and tradition, they consciously promoted their own culture and civilization.

African cultural practices contain elements of indigenous religion. But this was replaced by Islam mostly in the northern part of Nigeria and other parts of Africa by the 1700s. By the 1900s, Christianity was firmly entrenched in most parts of Africa including southern Nigeria. When the colonialists came, they seized all economic resources and divided them to those who embraced Christianity. This naturally created social upheaval which worked in favour of the colonizers. They condemned African traditional religion and culture and promoted theirs.

The most important area of domination was the mental universe of the colonized. (Ebine in Mangut and Wuam (eds.) 2012:795). This is because economic and political control cannot be fully achieved without mental control. To control African culture and its medium of transmission is to control their instrument of self-definition in relation to others. It is also to control how Africans perceive themselves and others in the world which is a way of perpetuating colonial domination in Africa forever.

The formal colonialism of African territories which began after the scramble for and partition of Africa in $1884 / 85$ in Berlin increased the economic exploitation of Africa backed up by military and political domination. Britain adopted the indirect rule policy at different times in many of her African colonies. This involved adapting traditional African political institutions to serve the administrative purposes of Britain. This meant the transformation of African chiefs whose powers came from colonial authorities rather than the traditional political institutions.

We have to quickly add that the British choice of Indirect Rule emanated more from the search for a solution to the economic problem of shortage of personnel and other logistics challenges rather than from a special regard for African traditional institutions (Omoni, 1982:81). Britain knew that it was not always necessary to set up formal colonial rule by making use of British personnel to reap the benefits of colonial domination. They knew that it was often cheaper and politically easier not to.

\section{AFRICAN MILITARY AND COLONIAL LEGACY}

Virtually all African States developed their own armies to protect themselves against threats of internal subversion and external aggression. (Akinyeye in Akindele and Ate (eds.) 2001:26). According to Ajayi, war was not a profession in Yoruba land until the nineteenth century, this was true of all African States except Egypt. (Ryder, 1969:68). Military service was a part-time duty incumbent on all able bodied male citizens, and they used locally made weapons. Only Egypt had a central army which was not standing but easily mobilized and used locally made weapons until its conquest by Turkey.

So in all African States war was a part-time vocation, but colonialism institutionalized and professionalized warfare. This was adopted by the independent nations of Africa, some of which are so militarized that the proliferation of firearms in the hands of cultists and gangs is fast becoming the norm.

The African military is a colonial creation. The majority of military officers in Nigeria and Ghana among other British colonies in Africa were trained at Sandhurst. Some of them are Afrija of Ghana and Ironsi of Nigeria, both army generals and trained in Sandhurst. (Ekpon Omoweh in Akindele and Ate (eds.) 2001:101). Most of the early officers in the African military also fought in World War II as troops of the British and French Forces. All these explain why the externalization of the African Security System and the character of its military derives from its colonial legacy.

After independence, the military regimes which succeeded the independence rulers carried on with the mentality of an army of occupation against their own people just like the colonial army. This has impoverished the African States and created political instability. This is a direct implication of the colonial administration which as an army of occupation had no regard for the rights of the people. The colonial army served the interest of their home government only. Unfortunately the African Armies and leaders copied this attitude which is working against their own people, the very people they are supposed to protect.

Colonial history is a history of oppression and brutality. Most importantly it is a history of mental and cultural colonialism. The legacy of this form of invasion, (cultural and mental invasion) lasts much longer than the political relationship and the impact is deeper because the damage is at the very essence of who we are as a people our identity. A people confused about their identity cannot function in their full capacity. Dealing with this past is a herculean task but it is even more problematic to simply ignore it. Many nations of the world have reclaimed their identity after colonialism, Nigeria and other African Nations can do the same. 
Culture refers to an integral system which demonstrates the values, beliefs, customs and institutions of a particular community, or group of communities. African historical experience since the fifteenth century has joggled the African culture, shattered her anthology and has left her confused.

The world has become a global village, therefore, certain fundamental changes that have taken place in the global system since the 1990 s, make Africa even more vulnerable than before. The end of the Cold War, end of apartheid in South Africa, collapse of the Soviet Union as a nation and super power and the emergence of the United States of America as the military hegemonic force in global system, - all have implications for African Security (Ekpo and Daniel in Akindele and Ate (eds.) 2001:102). So too have the emerging international economic order, political order, revolution in technological developments provided a more critical context. Suffice it to say that the intervention of Britain, French and Belgian troops and even the United Nations troops help to heighten African crisis since the international community always works for its interest. The African crisis is deepened because all the structures of the state have collapsed and there is no law and order (Thomas, 1994). Africa has allowed the colonialists not only to think for her even in the present but to determine its policy direction locally and internationally . That has to stop. It is also acting on and reacting to an agenda drawn up outside the Third World (Callaghy in Nelson (ed.), 1990:257-319).

Security is of great concern to all human societies because it impinges on the survival of every human being or society. (Imobighe in Akindele and Ate 2001:39).

Without security, individuals within a state will find it difficult to engage in productive activities and unable to effectively harness its human or material resources for meaningful development and the promotion of general welfare of the people. Actually, national security to the African leaders after independence was narrowed down to the interest and survival of that particular regime. Thus, the protection and self-preservation of the regime are interpreted as its core values (Ayoob, 1987: 36). But it is impossible to have security in a society yet to recover from its colonial heritage. The spate of current African conflicts most certainly has historical roots beyond the immediate currents.

The more reason it is expedient to make educated views derived from insightful knowledge of the past. Evidence abounds that effective sanctions and conflict management strategies utilized during the pre-colonial period reduced violent conflicts to the barest minimum. These strategies are rooted in the African culture and were very effective. Again the African belief system and religious thought pattern on the sacredness and sanctity of life and brotherhood, also helped in checking conflicts.

Socially, culturally and economically, the web of timehonoured institutions and cultural fabrics that served as anchors to the people both in times of war and peace, have largely become dysfunctional. (Okorobia in Derefaka and
Okorobia (eds.) 2007:4). This has created an atmosphere of near anarchy necessitating the resuscitation of the time honoured cultural values which were relegated to the background or outrightly abolished by the colonialists.

The twin forces of missionary activity and western education worsened the cleavages introduced by commercialization. Missionaries targeted the lower classes in societies and converted them. The new converts thus acquired new status which made them more important than the traditional authorities in many societies. This reversal of authority led to conflicts in many parts of Africa. This is so bad now that in Nigeria, religious affiliation is now the basis of political party organization. As such political parties no longer play the nationalist role they are expected to play further deepening the crisis.

In a Nutshell European plunder of non-European continents via the nexus of the Trans-Atlantic Slave trade, piracy, colonial imposition and other modes of violence provided Europe with the necessary primitive capital with which it invested in capitalist production. Rodney who was influenced by Marxist ideals and dependency theorists like Andre Gunder Frank posited that "what was called the development of Africa by the colonialists was a cyclical shorthand expression for the intensification of colonial exploitation in Africa to develop capitalist Europe." ( Rodney, 1972 ) This brought into existence the capitalist mode of production on a world scale. The huge profits brought industrial revolution which inspired the abolition of slave trade. The industrial revolution also brought cut-throat competition among European powers for source of raw materials and markets, giving rise to neo-imperialism and colonialism in Africa. Historical analysis given by Rodney on early patterns of dependency resonate with contemporary social and economic realities of globalization. Colonial legacies are alive and well across Africa.

This process was responsible for putting together the current nation-states of Africa whether they are operating federalism or unitary forms of nation-state. This same process forced the capitalist mode of production on them. It is a historical fact that these new African states were put together through outright conquest, treaties, conferences and conventions, annexation and protectorates or colonies or a combination of many. No debate, no consultation and no participation of Africans was needed before decrees were issued. The colonial regime was autocratic and undemocratic.

Consequently, mostly out of desperation, Africans began to participate in the colonial economy as middlemen, license buying agents, cash crop grading clerks, colonial tax officials, local chiefs or warrant chiefs, and the colonial bureaucracy in general, using their privileged positions in the colonial economy and administration. These new elements engaged in pilfering, graft, theft, fraud, falsifications, cheating and other vices to build small original primitive capital which they later invested in the colonial trade, transport, education, estate development, restaurants and other activities of colonial economy. 
Their advantage was that the colonial subjects saw them as close allies of the colonial administration and could not complain about their excesses except on very rare occasions. They committed all sorts of atrocities and got away with it because as colonial collaborators, they were protected by the colonial government. So they got away with many things thereby emerging as a nascent privileged class. This happened in a society that named and shamed badly behaved individuals before colonial rule. This gradually became a norm as exhibited by the politicians and public office holders in Africa today who are so irresponsible and greedy without thinking of the consequences of their actions. Actually at independence, many African leaders simply continued the colonial tradition of using coercive apparatus of state power against the very people they were supposed to protect.

No generation has the right to mortgage the rights of succeeding generations to the product and facilities of the environment, which exist in a given society. (Derefaka in Derefaka and Okorobia (eds.)2997:61). Unfortunately, that is the situation in Africa.

In the long run, the alien political style associated with primitive accumulation and foreign democracy, culminated in the militarization of politics in Africa, a colonial legacy that has been greatly reinforced since independence.

\section{INTERGROUP INTERACTIONS IN PRE- COLONIAL NIGERIA}

At this juncture, an analysis of the intergroup relationships in pre-colonial Nigeria and by extension Africa will yield several dividends in addition to clarifying the impact of colonialism on such interactions in the present.

Although people may share a single national history, each cultural group within the nation may have its own history which is also related to the national history. These cultural group histories and interactions help us understand the identity of the group. (Martin and Nakayama , 2005). When we ignore history, we usually come to wrongheaded conclusions about others that reinforce particular stereotypes.

The paradox is that we really cannot escape history even if we fail to recognize it or try to suppress it. So to the history of intergroup interactions we will turn.

Indeed the peoples of present day Nigeria and Africa started relating with one another in their present geographical setting during the formative years of their various polities, a period spanning several millennia before the imposition of colonial rule.

There were relationships between Nsukka and Igala/Idoma, Yoruba and Igala, Edo and Nupe and so on in Nigeria. (Alagoa, 2007). These early intergroup relations were underpinned by mutual accommodation, and perhaps the region was already evolving towards some form of unity before contact with Europe.
Indeed available evidence has shown that they so intermingled through trade that the ethnic lines separating them became blurred.

Besides it appears that diplomatic relations developed in some cases as a security measure. This was done through blood oaths or covenants, concubinage or intermarriage. Inter ethnic marriage was an important instrument of intergroup relations. This worked in two ways. The marriages promoted cordial relationships through the coming and going of in-laws on both sides and also proved useful in the settlement of disputes (Gobo in Derefaka and Okorobia (eds. ) 2007:295).

Furthermore, the hinterland communities were connected to their Delta neighbours by trade routes which led to areas noted for the production or distribution of agricultural or marine products.

Nevertheless, it would seem that political and diplomatic relations made the pre-colonial origins of Nigerian unity clearer. Various oral traditions of Nigeria are replete with evidence which suggest that various precolonial rulers, ruling houses and polities maintained diplomatic or political relationships. Such relationships promoted understanding among these groups. For instance, Benin and Ile-Ife ruling houses often relied on their past cordial relationship in resolving conflicts in Benin. The practice of getting help from older ruling houses to help them during succession disputes or sending their princes to well established and experienced rulers to learn the art and other imponderables associated with royalty was very common in pre-colonial Nigeria.

According to Alagoa, the practice of people going to Benin or sending presents to the Benin Monarch to validate their installations or to settle succession disputes among the western Niger Delta peoples of Ughelli, Ozoro, Lyede and Agbor was common. On the other hand, the Abraka are said to have sent their kings to the "Igbo" ruler of Aboh to seek the external recognition thought necessary to their internal prestige.

Even in recent times, the chiefs of the Tiv (Tor) are known to have been sent to serve a period of apprenticeship to learn the ceremonial and obtain insignia at the Jukun courts at Wukari in Katsina Ala.

Similary, Igala traditions state that every new chief of Aboh had to spend three months at Idah before investiture performing rituals and receiving instructions from the kings eunuchs. In the same vein, the Oba of Aboh was allowed to mediate in dispute at the court of Idah.

The Bayajida legend also ensured cordial relationships between Hausa-land and Borno for centuries. Their common ancestry was a uniting factor that encouraged a network of trading connections and other social interactions. 
These societies revealed a level of political integration much more complex than that of a community of related kins. Overlapping schemes for making, producing and distribution of wealth existed. Whenever one culture impinged on another in the frontier zones, they managed to fashion out over the centuries working relationships in which war and peace, marriage and diplomacy, trade and commerce, coming and going, give and take were the main elements.

These intergroup interactions cut across the continent. In fact, States of various types which share many characteristics with modern states existed in Africa. In West Africa were ancient Ghana, Mali, Songhai and Kanem Bornu. In the forest zone were Benin, Oyo, Dahomey, Asante and others. In East Africa were Babito kingdom of Bunyoro-kitara and Buganda. And in Central Africa was the Kongo kingdom(Akinyeye in Akindele and Ate(eds.) 2001: 20), just to name a few.

These states had recognizable governments and consisted of people of diverse nationalities. Moreover, even though their boundaries varied from time to time, they had definite territories at a particular time within which their authorities were well acknowledged, recognized and respected.

For instance, the Benin Empire in Nigeria consisted in addition to the Edo of Benin city, non-Edo groups such as Yoruba, Ajemai, Ishan, Urhobo and some Igbo groups (Ryder, 1969:20). Similarly, Oyo had non - Yoruba, Bariba, Aja and Nupe stock. The Asante polity exercised some control over non-Asante groups within and outside present day Ghana. Ancient Ghana had within its fold Madingo, Sanninke and other groups.

The Kongo kingdom was also multi-ethnic. So were the ancient kingdoms of Ethiopia, Kanem Bornu, Bunyorokitara, Songhai, Mwene, Mutapa, Egypt, Morocco, Tunisia and Algeria. Through this period, the concern was more with the control of economic resources and control over people.

The results of such relationships were the smothering out of the edges of cultural differences, and the moderations of conflicts arising from rival cultural chauvinism (Martin and Nakayama 2005: 145).

They accepted the need to abide by and respect local customs, traditions and institutions. But even when they had differences which caused war, it did not create any break in intergroup relations. War is a form of inter-group relationship which encourages cultural exchanges. Even enemies learned from one another's military strategies and tactics, borrowed or stole war medicines, gods and charms, weapons, and warlike social institutions such as the closely integrated age grades and secret societies that emphasized manliness, self-reliance and training in martial arts. (Gobo in Derefaka and Okorobia (eds.) 2007:297). It is also possible to learn the enemy's language and the borrowing of his dressing habits and other cultural traits for reasons of intelligence and espionage (Afigbo, 1980). After war, peace settlements were organized through the traditional conflict resolution mechanisms that were well established and time honoured to bring hitherto warring parties to a peaceful settlement. According to Cooley, "the more one thinks of it, the more he will see that conflict and cooperation are not separate things, but phases of one process which always involves something of both". (Sills 1986:235).

Various mechanisms were employed by the precolonial societies in Africa to heal breaches of peace which worked for centuries and kept the societies in relative peace and security. If avoidance of physical aggression did not successfully resolve a conflict, the use of a third party to achieve settlement by arbitration, mediation, compromise or adjudication was attempted. Attention must be drawn to the practice of princes learning the intricacies of governance in distant royal courts, or of people freely submitting their succession disputes for arbitration in the court of a respected chief without feeling inferior or threat of domination. Such traditions helped to establish meaningful cordial relationships. They further fostered a feeling of oneness and promoted mutual respect among the relating regions.

Equally important is the fact that attempts were made to solve communication problems by adopting some kind of lingua franca. In fact, African traders on the Niger were good linguists who spoke three to four languages for the purpose of trade and cultural interaction.

Understanding history is crucial to understanding the linguistic world we inhabit (Martin and Judith 2005:68). These interactions partly explain why most Nigerians and other Africans today speak many other languages and see it as normal. History to a large extent determines what languages we speak or do not speak. Such evidence of adoption, adaptation and even borrowing that characterized pre-colonial interactions assumes proper perspective when it is understood that some of the rulers saw themselves as brothers and frequently exchanged visits and ideas.

The Divide and Rule policy of the British which worked hand in hand with the British Indirect Rule policy further exploited and highlighted cultural differences for easy manipulation and domination. It is taken for granted that the colonial authorities would favour those who welcomed them to the disadvantage of those who opposed them. Such was the case of Britain in Northern Nigeria that accepted Islam and was more accommodating to the British unlike the Southern Nigeria which they found difficult to control.

This is similar to the case of Belgian colonial authority in its dealings with Hutu and the Tutsi in its territory of Rwanda - Burundi. The colonial intervention in Africa altered the nature of African states, their national interests and threats to these interests, as well as the means of protecting them (Akindele, and Bassey,(eds.), 2001: 29). 
In a piece - meal fashion, the colonial powers brought the countries of Africa under their control before considering how to administer them or knowing the extent and nature of the countries and their people. Hence, the wantom destruction and deliberate denigration of African sacred traditional institutions. The harm has been done already and the question is do we continue to play the blame game or forge ahead with the task of rebuilding our cultural heritage.

The total disregard for African culture and tradition was not an isolated case of the British in West Africa but a general mode of operation of all the colonial powers. For instance, the French from the onset of their colonial enterprise in Africa regarded her colonies as France Otremer (France Overseas) (Crowder, 1968:168). This racial and cultural arrogance displayed by France made her to disregard the culture of her colonial subjects by imposing the policy of assimilation by military fiat. The "assimiles' ' in French Africa represented the group Frantz Fanon calls the "benis oui oui" or "yes yes men". The elites in French Africa looked up to Paris as "home". This was because to become "assimile", one had to show signs of being "civilized". This meant being able to speak French, eat French food, dress the French way, be a Christian, be literate and abandon what the colonizer called "Primitive African Culture (Ebine in Mangut and Wuam (eds.) 2012:79).

All over Africa, the colonizers negotiated and drafted treaties with African leaders, stripping Africans of their lands, depopulating the countryside, destroying their economies, overturning political rule and uprooting cultural and lineage continuity. These created huge problems in Africa which have become thorny issues with grave implications.

The pre-colonial trade relation was altered by the European presence on the African coast from the fifteenth century. Not only did European presence increase the volume of trade between Europe and Africa, it also stimulated changes in the interactions between the coastal dwellers and their hinterland neighbours. (Mordi in Egbe (ed.) 2002:209). Trade rivalries soon led to wars between hitherto friendly communities due to the competition and lure of the coastal trade with the Europeans.

Britain provided infrastructure and facilities that completely upset the mostly serene equilibrium of precolonial intergroup relationship. They provided social amenities like hospitals, schools, pipe-borne water, and communication network for both strangers and host communities alike which they could lay equal claims to. All these which may be good in themselves, however created frequent collisions along cultural and ethnic lines. (Fayam in Akinwumi (eds.) 2006:447). Indirect Rule thus generated inquiries into cultural and political relationships and helped to whip up cultural and ethnic sentiments.
Most nation states do not possess some or all the important determinants of a nation yet there is a need to create national consciousness in these people and groups in the nation-state they have found themselves. (Rustow A.). Africa needs to do that.

Colonialism was bad. It was designed to benefit the colonizers at the detriment of the colonized. However, some persons are of the opinion that colonialism brought some benefits to Africans like the English and French languages, centralized state institutions and religion among other things. However, Alagoa has advised that these benefits should not be exaggerated as state institutions existed before the arrival of the Europeans in Africa as shown by the kinglists (Alagoa, 1989).

Alagoa also stated that the king and rulers received the Europeans on arrival and ensured their protection. Besides, he said whatever benefit Africa derived from the colonial experience could have been achieved through a simple means of exchange without one group enslaving the other. Rodney also corroborated this by stating that whatever benefit Africa got from colonialism was accidental and not intentional. I personally see nothing good about colonialism because there is no good way of doing a bad thing. Because of colonialism, Africans will never know what their full potential would have been without colonialism and its instruments of domination and exploitation.

\section{CONCLUSION}

An attempt has been made in this study to highlight some of the historical foundation of the current development crises in Africa as it relates to the colonial legacy. Some people are of the opinion that colonialism also benefited Africa. I refuse to see that because there is nothing positive about a crime against humanity just like there is no good way of doing a bad thing

However, the colonial legacies discussed above are some of the reasons for the state of affairs in Africa but not an excuse. Africa must stop making excuses for bad choices. Other nations of the world also experienced colonialism and still managed to attain enviable development strides. Africa managed its problems relatively well in pre-colonial times, it is therefore reasonable to suggest that solutions to its contemporary problems are best sought from within. The salvation of Africa will not come from outside Africa because no capitalist genuinely wants to create other capitalists who will compete with him. Therefore, practical steps should be taken by Africans to salvage the African continent from its colonial vestiges. 


\section{RECOMMENDATIONS}

African elites, leaders and policy makers should all agree on the conception of the state, its structure and functions.

There is a need to redefine and redesign the concept of African development to reflect the current reality of the African situation.

$>$ This should not be patterned along western lines and should not be the exclusive preserve of the state and it's cohorts but all inclusive, carrying everybody along. This will promote peace among the people and ultimately among the nation-states of Africa.

> African leadership and followership must understand that the current identity crises and cultural confusion experienced in Africa is not just as a result of such "legacy", rather it is due to the utter failure of the African leadership to assert its hegemony within Africa after colonialism.

$>$ Practical steps should be taken to salvage the African continent from the negative effects of its colonial heritage.

> Political will is required across the continent to save Africa. This must be done consciously, deliberately and intentionally with all sincerity of purpose.

$>$ Unfortunately in Africa, the quality of leadership has been dropping in descending order from the colonial period. The followers must rise up and reject bad leadership in any form and at any level.

\section{REFERENCES}

[1]. Afigbo, A. E. (1972). The Warrant Chiefs: Indirect Rule in South Eastern Nigeria, 1891-1929. London. Longman Group Limited.

[2]. Afigbo, A. E. (1980). External Contacts and Relations: An Overview in M. B. Abasiattai (ed.). A History of the Cross River Region of Nigeria. Enugu: Harris Publishers Limited.

[3]. Akindele, R. A. and Bassey E. A. (eds.) (2001). Beyond Conflict Resolution: Managing African Security in the Twenty First Century. Ibadan Vantage Publishers.

[4]. Akinwunmi et al (2006). Inter-Group Relations In Nigeria During The $19^{\text {th }}$ And $20^{\text {th }}$ Centuries. Makurdi. Aboki Publishers.

[5]. Alagoa, E. J. (2007). The Practice of History in Africa: A History of African Historiography. Port Harcourt. Onyoma Research Publications.

[6]. Alagoa, E. J. and Derefaka, A. A. (2002). The Land and People of Rivers State: Eastern Niger Delta. Port Harcourt. Onyoma Research Publications.

[7]. Callaghy, T. M. (1990). Lost between the State and Market: The Politics of Economic Adjustment in Ghana, Zambia and Nigeria in J. Nelson (ed.). "Economic Crisis and Policy Choice: The Politics of Adjustment in the Third World." Princeton: Princeton University Press.

[8]. Derefaka, A. A, (2003). Archaeology and Culture History in the Central Niger Delta. Port Harcourt. Onyoma Research Publications.
[9]. Derefaka, A. A. and Okorobia, A. M. (2007). The Future of the Niger Delta: The Search for a Relevant Narrative. Port Harcourt. Onyoma Research Publications.

[10]. Glezemman, G. (1980). Classes and Nations. Moscow Progress Publishers.

[11]. Ifie, Egbe, (ed.) (2002). Papers in Honour of Tekena Nitonye Tamuno: Professor Emeritus at 70. Ibadan. Oputoru Books, 2002.

[12]. Mangut, J. and Wuam, T. (2012). Colonialism and the Transition to Modernity in Africa. Ibadan Sam - Adex Printers.

[13]. Martin J. N. and Nakayama T. K. (2005). Experiencing Intercultural Communication: An Introduction. New York. Mc Graw-Hill.

[14]. Mohammed, A. (1987). Regional Security and the Third World in "Regional Conflict and Global Security in the 1990s (Vol, 1)." University of Wisconsin, Madison: Center for International Cooperation and Security Studies.

[15]. Nwabughuogu, A. I. (2004). Problems of Nation Building in Africa. Okigwe. Fasmen Communications.

[16]. Obiozor, G. A. (1994). The Politics of Precarious Balancing: An Analysis of Contending Issues in Nigerian Domestic and Foreign Policy. Nigeria Institute of International Affairs.

[17]. Ogwu, U. J. and Olukoshi, O. A. (1991). The Economic Diplomacy of the Nigerian State. Lagos. Frankad Publishers.

[18]. Olagunji, T. and Oyovbaire, S. (1991). For Their Tomorrow We Gave Our Today: Selected Speeches of President Ibrahim Babangida Volume II, Ibadan, Safari Books Limited.

[19]. Reynolds, P. A. (1974). The International Environment, in James B. and Michael S. (eds.). The Nature of Foreign Policy: A Reader Boughall and OUP.

[20]. Sills, D. L. (1968). International Encyclopedia of the Social Sciences, Volume III: London. Macmillan Company and the Free Press.

[21]. Tamuno, T. N. (2000). The Niger Delta Question. Port Harcourt, Riverside Communications.

[22]. Tamuno, T. N. (ed.) (1984). The Civil War Years: Proceedings of The National Conference on Nigeria Since Independence. Volume III. Zaria. Gaskiya Corporation Limited.

[23]. Thompson, J. M. (1962). Lectures on Foreign History 1494-1789. Oxford. Basil Blackwell.

[24]. Ugiomoh, F. A. O. et al (eds.) (2017). Religion and the Bounds of Culture. Festschrift in Honour of Prof. C. I. Ejizu. Port Harcourt. Rock Publishers.

\section{* Articles}

[25]. Asian Development Bank, 2000: Pacific Studies Series - Samoa.

[26]. John O. Kakonge. "The Role of Culture in Africa's Development -

[27]. March 30, 2017.

[28]. Journal of Niger Delta Studies. Volume 4, 2015. No. 1. 
[29]. "NEPAD in the Nigerian Dock". Proceedings of a Conference organized by The Nigerian Institute of International Affairs in Collaboration with The Friedrich Foundation. 2004.

[30]. The Future We Want, United Nations Conference on Sustainable Development (Rior20) Rio de Janeiro, Brazil, 20 - 22, June 2012.

[31]. The Pacific Plan, Pacific Island Forum. 2005.

* Internet Sources

[32]. http://en.unesco.org

[33]. pambazuka.org

[34]. https://wikipedia.org

[35]. www.pulse.ng

[36]. researchgate.net

[37]. pindfoundation.org

[38]. www.kwintessential.co.uk/culturalservices/articles/introduction-intercultural.html]/ 